\title{
The effects of excessive amounts of protein on lysine utilization in growing pigs
}

\author{
BY STEFAN LANGER* AND MALCOLM F. FULLER \\ Rowett Research Institute, Greenburn Road, Bucksburn, Aberdeen AB2 9 SB
}

(Received 11 September 1995 - Revised 22 January 1996-Accepted 26 February 1996)

\begin{abstract}
Two experiments were conducted to investigate whether the utilization of lysine in growing pigs is affected by the level of excess protein in the diet. Nine lysine-deficient diets containing 100,200 or $300 \mathrm{~g}$ crude protein $/ \mathrm{kg}$ and between 1.2 and $6.8 \mathrm{~g}$ ileal digestible lysine/kg were prepared. In the first experiment the apparent ileal digestibility of lysine in three of the nine diets was determined using pigs with simple $\mathrm{T}$-cannulas and $\mathrm{Cr}_{2} \mathrm{O}_{3}$ as an indigestible marker. Ileal digestibility of lysine in the other diets was calculated by interpolation. In the second experiment $\mathrm{N}$ retention, as a measure of lysine utilization, was determined in all nine diets using growing pigs over the weight range $30-50 \mathrm{~kg}$. The effect of excess protein on lysine utilization was assessed by comparing the regression of $\mathrm{N}$ retention $\boldsymbol{v}$. lysine (ileal digestible) intake at the three levels of protein. Increasing ileal digestible lysine in the diets resulted in a linear increase in $\mathbf{N}$ retention with all three protein levels and there was no significant difference amongst the three regressions, indicating that lysine utilization was not affected by the level of protein. Therefore, all data were pooled together to calculate a single regression for all treatments. An increase of $1.0 \mathrm{~g}$ ileal digestible lysine led to an increase of $1.43 \mathrm{~g} \mathrm{~N}$ or $8.96 \mathrm{~g}$ protein $(\mathrm{N} \times 6.25)$ retained. Assuming a lysine concentration in the retained body protein of $65-72 \mathrm{mg} / \mathrm{g}$, lysine was utilized with an efficiency of $0.58-0.65$.
\end{abstract}

Protein intake: Lysine: Ileal digestibility: Amino acid imbalance: Pig

The importance of the relative balance among amino acids as a factor in protein quality is firmly established although, in conventional diet formulation, amino acid excesses are normally disregarded. For instance, the chemical score method (Mitchell \& Block, 1946), used for estimating protein quality, is based on the premise that the performance of an animal fed on an amino acid-deficient diet is solely dependent on the level of the limiting amino acid, if all other nutrients are supplied in sufficient amounts. Protein concentration and amino acid excesses in the diet seem to play a minor role as long as the minimal requirement for the limiting amino acid is met. However, numerous reports indicate that excesses of amino acids decrease animal performance (D'Mello \& Lewis, $1970 a-c$; Harper et al. 1970; Benevenga \& Steele, 1984) and several papers (Mørup \& Olesen, 1976; Berschauer et al. 1980; Menke et al. 1983; Cieslak \& Benevenga, 1986) suggest that the chemical score method should be modified by taking account of the excesses of other amino acids.

In general, the main response to excessive amounts of amino acids is reduced feed intake. However, even at constant intake, metabolic interactions between amino acids can result in a reduction of protein utilization and consequently animal performance (D'Mello, 1994).

Lysine is usually the first-limiting amino acid in cereal-based diets and most other amino acids are in relative excess. Using natural ingredients to meet the requirement for lysine (i.e. without addition of industrially produced lysine), these excesses are unavoidable. This

\footnotetext{
* Present address: Ralston Purina Europe Inc., European R \& T Department, 1 Place Charles de Gaulle, BP 301, 78054 Saint-Quentin-en-Yvelines Cedex, France.
} 
raises the question as to whether such a surplus of amino acids affects the utilization of lysine under the feeding conditions used in practical pig and poultry production where even small changes in lysine utilization would be of great economic importance.

The influence of amino acid excesses on lysine utilization has been investigated in various species over the last decades (Fisher et al. 1960; Klay, 1964a, b; Chamberlain, 1971; Cieslak \& Benevenga, 1984a, b; 1986; Morris et al. 1987; D’Mello, 1988; Abebe \& Morris, 1990; Henry et al. 1992). However, there is very little consistent information about the effects of protein or amino acid excess on lysine utilization in growing pigs. Klay $(1964 a, b)$ investigated the effect of dietary protein $(100-260 \mathrm{~g}$ crude protein $/ \mathrm{kg}$ diet) on lysine utilization using lysine concentrations of between 6.3 and $11 \cdot 1 \mathrm{~g} / \mathrm{kg}$ diet. Comparing weight gain and feed conversion efficiency (daily weight gain/daily feed intake) of growing pigs he reported a linear decrease of gain and efficiency with increasing levels of dietary protein. Additionally, true digestibility of lysine decreased with increasing level of protein. The author concluded that decreased absorption of lysine might be the reason for the reduced growth and efficiency of pigs fed on diets containing higher levels of protein.

Increasing the protein concentration from 131 to $158 \mathrm{~g} / \mathrm{kg}$ in a lysine-deficient diet (approximately $5.6 \mathrm{~g}$ lysine $/ \mathrm{kg}$ diet) had no effect on feed intake but reduced daily weight gain and feed-conversion efficiency of growing pigs (Henry et al. 1992). In contrast, the addition of glutamic acid to increase $\mathbf{N}$ concentration reduced feed intake and daily weight gain but had no effect on feed-conversion efficiency. The authors suggested that the lower efficiency was caused by the additional energy expended in the catabolism of excess protein. Fuller et al. $(1987 a, b)$ compared $\mathrm{N}$ retention of pigs fed on lysine-deficient diets with protein concentrations of either 156 or $302 \mathrm{~g} / \mathrm{kg}$ diet and reported both a positive (1987a) and a negative $(1987 b)$ influence of protein on lysine utilization. However, none of these differences was significant and the experiments were not designed to measure lysine utilization.

Cieslak \& Benevenga $(1984 a, b)$ concluded that the effects of protein excesses on growth performance in rats were almost entirely due to changes in voluntary feed intake. Fisher et al. (1960) came to a similar conclusion from their investigation of feed intake, growth performance and the efficiency of lysine utilization in growing chicks.

The objective of the present study was to investigate the effect of different levels of protein on lysine utilization based on the amount of apparent ileal digestible lysine. These results were reported briefly to the Nutrition Society (Langer and Fuller, 1995).

\section{MATERIALS AND METHODS}

Animals and housing conditions

Expt 1. Six female Cotswold crossbred pigs (25-30 kg body weight) were each provided with a simple T-cannula inserted $100-150 \mathrm{~mm}$ anterior to the ileo-caecal junction. After 2 weeks recovery from surgery the animals were gradually adapted to the experimental conditions. During the experiment the animals were housed individually in large, concretefloored pens without bedding material. Room temperature was kept constant at $22-24^{\circ}$. The initial mean weight of the pigs was 33.9 (SD 2.4) $\mathrm{kg}$ and their final weight was 39.2 (SD 2.9$) \mathrm{kg}$.

Expt 2. Eighteen female Cotswold crossbred pigs were used. On the third day of the first period the pigs were moved from open pens to metabolism cages. At the end of the second period there was a rest period in open pens, then the pigs were moved back to the metabolism cages. Room temperature was maintained at $22-24^{\circ}$. At the beginning of the experiment the animals had a mean weight of $31 \cdot 1$ (SD 2.0) $\mathrm{kg}$ and at the end $49 \cdot 1$ (SD $3 \cdot 3) \mathrm{kg}$. 
Table 1. Composition of basal diet and dilution mixture $(\mathrm{g} / \mathrm{kg})$

\begin{tabular}{|c|c|c|}
\hline Ingredients & Basal diet & Dilution mixture \\
\hline Maize & $300 \cdot 0$ & - \\
\hline Wheat & $299 \cdot 2$ & - \\
\hline Maize gluten & 246.4 & - \\
\hline Feather meal & $100 \cdot 0$ & - \\
\hline Maize starch & 一 & $572 \cdot 4$ \\
\hline Glucose & - & $165 \cdot 0$ \\
\hline Sugar & - & $100 \cdot 0$ \\
\hline Cellulose & - & $66 \cdot 0$ \\
\hline Oil (vegetable) & $20 \cdot 0$ & $40 \cdot 0$ \\
\hline Mineral and vitamin mixture $\mathbf{B}^{*}$ & $27 \cdot 0$ & - \\
\hline Mineral and vitamin mixture $\mathrm{D} \dagger$ & - & $56 \cdot 6$ \\
\hline Threonine & $2 \cdot 7$ & - \\
\hline DL-Methionine & $1 \cdot 0$ & - \\
\hline Histidine- $\mathrm{HCl}$ & 1.9 & - \\
\hline Tryptophan & 1.8 & - \\
\hline
\end{tabular}

* The basal diet contained ( $\mathrm{g} / \mathrm{kg}$ diet): Pigvite No. 12 (Norvite Feed Supplements, Aberdeenshire) 2.5, dicalcium phosphate $(48 \%) 22.0$, sodium chloride 2.0 and limestone 0.5 .

+ The dilution mixture contained (g/kg diet): Pigvite No. $122 \cdot 5$, dicalcium phosphate (48\%) $40 \cdot 0$, sodium chloride $1 \cdot 0$, potassium carbonate 7.0 , magnesium oxide 0.7 , Vitamin $\mathbf{B}_{12}$ Customix (Norvite Feed Supplements) $1 \cdot 5$, choline chloride $(100 \%) 1 \cdot 15$ and $(\mathrm{mg} / \mathrm{kg}$ diet) iron sulphate 96.0 , nicotinic acid $9 \cdot 1$, pteroylglutamic acid $2 \cdot 0$, biotin $(2 \%) 2 \cdot 5$, pantothenic acid $6 \cdot 8$, pyridoxine $2 \cdot 7$, thiamin $2 \cdot 0$, riboflavin $0 \cdot 9$, inositol $150 \cdot 0$ and ascorbic acid $12 \cdot 0$.

Table 2. Composition and analysis of experimental diets

\begin{tabular}{|c|c|c|c|c|c|c|c|c|c|}
\hline \multirow[b]{2}{*}{ Diet no... } & \multicolumn{4}{|c|}{ Low crude protein } & \multicolumn{3}{|c|}{ Medium crude protein } & \multicolumn{2}{|c|}{ High crude protein } \\
\hline & 1 & 2 & 3 & 4 & 5 & 6 & 7 & 8 & 9 \\
\hline \multicolumn{10}{|l|}{ Ingredients $(\mathrm{g} / \mathrm{kg})$} \\
\hline Basal diet & $333 \cdot 3$ & $333 \cdot 3$ & $333 \cdot 3$ & $333 \cdot 3$ & $666 \cdot 6$ & $666 \cdot 6$ & $666 \cdot 6$ & $1000-0$ & 997.6 \\
\hline Dilution mixture & $666 \cdot 7$ & $664 \cdot 3$ & $661 \cdot 9$ & $659 \cdot 6$ & $333 \cdot 3$ & $331 \cdot 0$ & 328.6 & - & - \\
\hline Lysine-HCl* & - & $2 \cdot 37$ & $4 \cdot 74$ & $7 \cdot 11$ & - & $2 \cdot 37$ & $4 \cdot 74$ & - & $2 \cdot 37$ \\
\hline \multicolumn{10}{|l|}{ Analysis (g/kg) } \\
\hline Dry matter & $897 \cdot 3$ & $899 \cdot 0$ & $894 \cdot 5$ & $894 \cdot 0$ & $891 \cdot 9$ & $892 \cdot 8$ & $889 \cdot 2$ & $888 \cdot 8$ & $894 \cdot 8$ \\
\hline Neutral-detergent fibre $\dagger$ & 78.0 & $78 \cdot 0$ & 78.0 & 78.0 & $84 \cdot 5$ & 84.5 & $84 \cdot 5$ & $91 \cdot 0$ & 91.0 \\
\hline Crude protein & $102 \cdot 2$ & $102 \cdot 4$ & $108 \cdot 0$ & $111 \cdot 8$ & $196 \cdot 3$ & $200 \cdot 6$ & $199 \cdot 0$ & $298 \cdot 8$ & $307 \cdot 0$ \\
\hline Lysine & 2.08 & $4 \cdot 03$ & $5 \cdot 52$ & $7 \cdot 40$ & $4 \cdot 48$ & 6.46 & 8.36 & 6.69 & 8.22 \\
\hline Digestible energy $(\mathrm{MJ} / \mathrm{kg}) \ddagger$ & $13 \cdot 43$ & $13 \cdot 43$ & $13 \cdot 43$ & $13 \cdot 43$ & $13 \cdot 78$ & 13.78 & $13 \cdot 78$ & $14 \cdot 13$ & $14 \cdot 13$ \\
\hline
\end{tabular}

* Free lysine was added as the monochlorohydrate form, taken to contain $0.785 \mathrm{~g} \mathrm{lysine} / \mathrm{g}$.

$\uparrow$ Determined for low- and high-crude-protein diets ( 1 and 8$)$ and calculated for medium-crude-protein diets by interpolation.

$\ddagger$ Calculated values.

\section{Diets and feeding}

Nine diets containing 100,200 or $300 \mathrm{~g}$ crude protein $/ \mathrm{kg}$ (low protein (LP), medium protein (MP), high protein (HP)) were formulated using different ratios of a basal diet and a protein-free dilution mixture (Table 1). Free lysine was added (Table 2 ) to form diets with the same lysine concentration but different levels of protein. The lowest concentration of lysine in the protein $(20 \mathrm{~g} / \mathrm{kg})$ was the minimum that could be achieved using available 
conventional ingredients: the highest $(66 \mathrm{~g} / \mathrm{kg})$ was the concentration in 'ideal protein' according to the results of Wang \& Fuller (1989). Between these limits free lysine was added in equal increments. Both the basal diet and the dilution mixture were calculated to be isoenergetic and to contain similar amounts of fibre (Table 2). The basal diet was supplemented with threonine, methionine, histidine and tryptophan to ensure adequacy of these essential amino acids. The calculation was based on true ileal digestible amino acids according to the recommended 'ideal pattern' of amino acids for growing pigs determined by Wang \& Fuller (1989). To examine the effects on lysine utilization unconfounded by variation in the consumption of the diets, animals in both experiments had a daily feed allowance of $85 \mathrm{~g} / \mathrm{kg}$ body weight $(\mathrm{BW})^{0.75}$, given in three equal meals at $08.00,12.00$ and 16.00 hours. Water was added to the feed in the trough and was also freely available throughout the experiments.

Marker. In Expt 1, $\mathrm{Cr}_{2} \mathrm{O}_{3}$ mordanted to cellulose, prepared according to the method described by Udén et al. (1980), was used as a marker and added to the diets at a level of $20 \mathrm{~g} / \mathrm{kg}$. In order to avoid the possibility of particle separation this was added to small batches of diet rather than the entire mix.

\section{Experimental design and sample collection}

Expt 1. Amino acid and $\mathrm{N}$ digestibilities at the terminal ileum were determined in diets 1,3 and 8. After a $7 \mathrm{~d}$ adaptation period to a diet made of equal amounts of the three diets, the animals and diets were arranged in two $3 \times 3$ Latin squares. Each animal received the three diets in three successive $7 \mathrm{~d}$ periods. This gave a total of six observations per diet and three observations per animal. After a $5 \mathrm{~d}$ adaptation period, ileal digesta were collected during two successive days. Following the first meal of day 6 the cannula was opened and cleaned, a collection bag was attached, and all digesta passing through were collected from 09.00 to 20.00 hours. As soon as digesta appeared in the bag, they were rapidly removed and frozen $(<10 \mathrm{~min}$ ) to avoid any further digestion or microbial fermentation.

Expt 2. After $4 \mathrm{~d}$ adaptation to a mixed diet (as described previously) the pigs received their treatment diets. The experiment included eighteen pigs on each of which measurements were made in three successive periods. Each pig was given a sequence of three diets and each set of three animals received all nine diets. The design was further constrained by arranging that each diet was allocated to only two pigs in each period. The design can therefore be considered as an incomplete block design with animals forming the blocks. Each period consisted of $5 \mathrm{~d}$ adaptation to the specific diet and $7 \mathrm{~d}$ measurement. To determine $\mathrm{N}$ retention, bladder catheters for urine collection were introduced before the measurement as described by Fuller et al. (1979). Faeces were collected for $7 \mathrm{~d}$. Urine was collected for two $48 \mathrm{~h}$ periods during the last $4 \mathrm{~d}$ of each measurement period

\section{Sample storage and chemical analysis}

Diet samples were stored at $+4^{\circ}$. Determinations of dietary protein content $(\mathrm{N} \times 6.25)$ and $\mathrm{N}$ concentrations in urine, digesta and faeces were carried out after macro-Kjeldahl digestion as described by Davidson et al. (1970). Amino acid concentrations in diet and digesta samples were determined by reverse-phase liquid chromatography (Waters Pico Tag ${ }^{(}$analyser; Waters Ltd, Watford, Herts.). Samples (approximately $10 \mathrm{mg} \mathrm{N}$ ) were hydrolysed for $18 \mathrm{~h}$ in $200 \mathrm{ml} 6 \mathrm{M}-\mathrm{HCl}$ at about $137^{\circ}$. Norleucine was used as an internal standard. In order to avoid accumulation of $\mathrm{Cr}_{2} \mathrm{O}_{3}$ in the analyser column, sample hydrolysates were cleaned using a small disposable column (Dowex 50W(X8) in Bio-Rad ${ }^{(}$ Poly Prep $8 \times 40 \mathrm{~mm}$ ).

The digesta samples were stored for $1-2 \mathrm{~d}$ in aluminium trays at $-20^{\circ}$. Frozen samples 
were freeze-dried and ground in a freezer mill for analysis. Samples from $2 \mathrm{~d}$ were pooled to give a composite sample for each pig. Freeze-dried digesta samples were stored at $+4^{\circ}$. $\mathrm{Cr}_{2} \mathrm{O}_{3}$ concentrations of digesta samples and diets were analysed as described by Stevenson \& Clare (1963).

To preserve the faeces and urine during the collection periods, $\mathrm{H}_{2} \mathrm{SO}_{4}(2 \mathrm{M} ; 200 \mathrm{ml} / \mathrm{d}$ for urine and $500 \mathrm{ml} / \mathrm{d}$ for faeces) was added to the containers. Faeces were homogenized and aliquot samples of both urine and faeces were stored at $-20^{\circ}$.

\section{Statistical analysis}

The marker: $\mathrm{N}$ ratio in digesta samples from days 6 and 7 of each period was compared before pooling, using a paired $t$ test. The data for ileal lysine and $\mathrm{N}$ digestibilities were analysed using REML (Genstat 5 Committee, 1993) with animal and period considered as random effects and diet as a fixed effect. The effect of protein on the regressions of $\mathrm{N}$ retention $v$. lysine intake (ileal digestible) was determined by regression analysis using Genstat 5.2. Effects were considered significant when $P<0.05$.

\section{RESULTS}

Expt 1

All pigs recovered quickly from the surgery and there were no signs of illness throughout the experiment. The proportion of digesta sampled was about $45 \%$ (calculated from the recovery of $\mathrm{Cr}_{2} \mathrm{O}_{3}$ ). Values for the single animals ranged from $23 \cdot 7-65 \cdot 2 \%$. There was no difference in the marker: $\mathrm{N}$ ratio between the two digesta collections; therefore, it could be assumed that the passage of the marker (days 6 and 7) reached an equilibrium.

Calculation of apparent ileal digestibility. The apparent ileal digestibility (ADTI) of N and lysine was determined according to the following equation:

$$
\mathrm{ADTI}=1-\frac{m_{f} \times n_{d}}{n_{f} \times m_{d}},
$$

where $m_{f}$ is the concentration of marker $\left(\mathrm{Cr}_{2} \mathrm{O}_{3}\right)$ in feed $(\mathrm{g} / \mathrm{kg}), n_{f}$ in the concentration of nutrient $\left(\mathrm{N}\right.$, lysine) in feed $(\mathrm{g} / \mathrm{kg}), m_{d}$ is the concentration of marker in digesta $(\mathrm{g} / \mathrm{kg})$, and $n_{d}$ is the concentration of nutrient in digesta $(\mathrm{g} / \mathrm{kg})$.

Apparent ileal nitrogen (protein) digestibility. The estimates of apparent $\mathrm{N}$ digestibility at the terminal ileum (ANDTI) are shown in Table 3. Ileal $\mathrm{N}$ digestibilities increased slightly from 0.74 to 0.76 in the LP diets to $0.77-0.78$ in the HP diets.

Apparent lysine digestibility. Diets 1, 3 and 8 had mean ileal lysine digestibility values of 0.58 (SE 0.015), 0.85 (SE 0.015) and 0.69 (SE 0.015) respectively (Table 4). Addition of free lysine to diet 1 to produce diet 3 led to a higher lysine digestibility. The HP diet (diet 8) had a higher apparent lysine digestibility than the LP diet (diet 1), which was made by $1: 2$ dilution of diet 8 with a protein-free dilution mixture. Using the results for diets 1,3 and 8 the ileal digestibility values of lysine in the other diets were calculated (Table 4).

\section{Expt 2}

Apparent faecal nitrogen digestibility. Results from two pigs on diet 8, which refused large amounts of feed and had problems with their bladder catheters, were excluded. Apparent (faecal) $\mathrm{N}$ digestibility (ANDF) for all nine diets was determined from the difference between $\mathrm{N}$ intake and $\mathrm{N}$ in faeces (Table 3). Apparent faecal $\mathrm{N}$ digestibilities were significantly higher than the ileal $\mathrm{N}$ digestibilities determined in Expt 1. Nevertheless, like the ileal digestibilities, the faecal values were slightly greater with higher dietary protein concentration. 
Table 3. Apparent ileal (ANDTI) and faecal $(A N D F)$ digestible nitrogen values for nine diets with differing protein and lysine contents fed to pigs*

\begin{tabular}{|c|c|c|c|c|c|c|c|c|c|c|}
\hline \multirow{2}{*}{$\begin{array}{l}\text { Protein level... } \\
\text { Diet number... }\end{array}$} & \multicolumn{4}{|c|}{ Low crude protein } & \multicolumn{3}{|c|}{ Medium crude protein } & \multicolumn{2}{|c|}{ High crude protein } & \multirow[b]{2}{*}{ Pooled SED } \\
\hline & 1 & 2 & 3 & 4 & 5 & 6 & 7 & 8 & 9 & \\
\hline ANDTI & 0.74 & $0.75 \dagger$ & 0.75 & $0.76 \dagger$ & $0.75 \dagger$ & $0.76 \dagger$ & $0.77 \dagger$ & 0.77 & $0.78 \dagger$ & 0.018 \\
\hline ANDF & $0.83^{\mathrm{a}}$ & $0 \cdot 84^{\mathrm{ab}}$ & $0 \cdot 84^{\mathrm{ab}}$ & $0.84^{\mathrm{ab}}$ & $0.86^{\text {be }}$ & $0.87^{\mathrm{c}}$ & $0.87^{\mathrm{c}}$ & $0.88^{\mathrm{c}}$ & $0.87^{\mathrm{c}}$ & $0 \cdot 014$ \\
\hline
\end{tabular}

a, h,c Mean values within a row not sharing a common superscript letter were significantly different $(P<0 \cdot 05)$.

* For details of diets see Tables 1 and 2.

$\uparrow$ Values calculated by interpolation.

Table 4. Ileal lysine digestibility and concentration $(\mathrm{g} / \mathrm{kg}$ diet) for nine diets differing in protein and lysine contents fed to pigs*

\begin{tabular}{|c|c|c|c|c|c|c|c|c|c|c|}
\hline \multirow{2}{*}{$\begin{array}{l}\text { Protein level... } \\
\text { Diet number ... }\end{array}$} & \multicolumn{4}{|c|}{ Low crude protein } & \multicolumn{3}{|c|}{ Medium crude protein } & \multicolumn{2}{|c|}{ High crude protein } & \multirow[b]{2}{*}{ Pooled SED } \\
\hline & 1 & 2 & 3 & 4 & 5 & 6 & 7 & 8 & 9 & \\
\hline Digestible lysine & $1 \cdot 21$ & $3 \cdot 14 \dagger$ & $4 \cdot 69$ & $6.56 \dagger$ & $2.89+$ & $4.84 \dagger$ & $6 \cdot 74 \dagger$ & $4 \cdot 74$ & $6 \cdot 34 \dagger$ & - \\
\hline Lysine digestibility & $0 \cdot 58^{\mathrm{a}}$ & $0.78 \dagger$ & $0 \cdot 85^{\mathrm{b}}$ & $0.89 \uparrow$ & $0.65 t$ & $0.75 \dagger$ & $0.81 \dagger$ & $0.69^{c}$ & $0.77 \dagger$ & 0.021 \\
\hline
\end{tabular}

a,b.e Mean values within a row with unlike superscript letters were significantly different $(P<0.05)$.

* For details of diets see Table 1 and 2.

$\dagger$ Values calculated by interpolation.

Nitrogen retention. Increasing ileal digestible lysine concentration resulted in a linear increase in $\mathrm{N}$ retention at all three protein levels. There was no significant difference amongst the three regressions of $\mathrm{N}$ retention on lysine intake, indicating that excess protein had no effect on lysine utilization. Therefore, all data were pooled together to calculate one single regression line for all treatments. $\mathrm{N}$ retention $(y, g / d)$ was related to ileal digestible lysine intake $(x, \mathrm{~g} / \mathrm{d})$ by the equation:

$$
y=1.43(\text { SE } 0.078) x+2.37(\text { SE } 0.515) \quad\left(r^{2} 0.87\right) .
$$

Fig. 1 summarizes the effect of increasing intake of ileal digestible lysine on $\mathrm{N}$ retention at three levels of dietary protein.

Assuming that $1 \mathrm{~g}$ body protein has $160 \mathrm{mg} \mathrm{N}$, an increase of $1 \mathrm{~g}$ ileal digestible lysine would increase protein deposition by about $8.96 \mathrm{~g}$. The equation for the relationship between protein retention $(y, \mathrm{~g} / \mathrm{d})$ and ileal digestible lysine intake $(x, \mathrm{~g} / \mathrm{d})$ was thus:

$$
y=8.96 x+14.78 \quad\left(r^{2} 0.87\right) .
$$

At any intake of digestible lysine $\mathrm{N}$ retention was the same for diets with free lysine as with protein-bound lysine, suggesting that the lysine in the basal diet was fully available.

Efficiency of lysine utilization. Assuming that $1 \mathrm{~g}$ body protein contains about $65 \mathrm{mg}$ lysine (the mean value from Batterham et al. 1990 b), the efficiency of utilization of the absorbed lysine could be calculated. The relationship between the rate of lysine retention $(y, \mathrm{~g} / \mathrm{d})$ and ileal digestible lysine $(x, \mathrm{~g} / \mathrm{d})$ was described by the equation:

$$
y=0.58 x+0.96 \quad\left(r^{2} 0 \cdot 87\right) \text {. }
$$




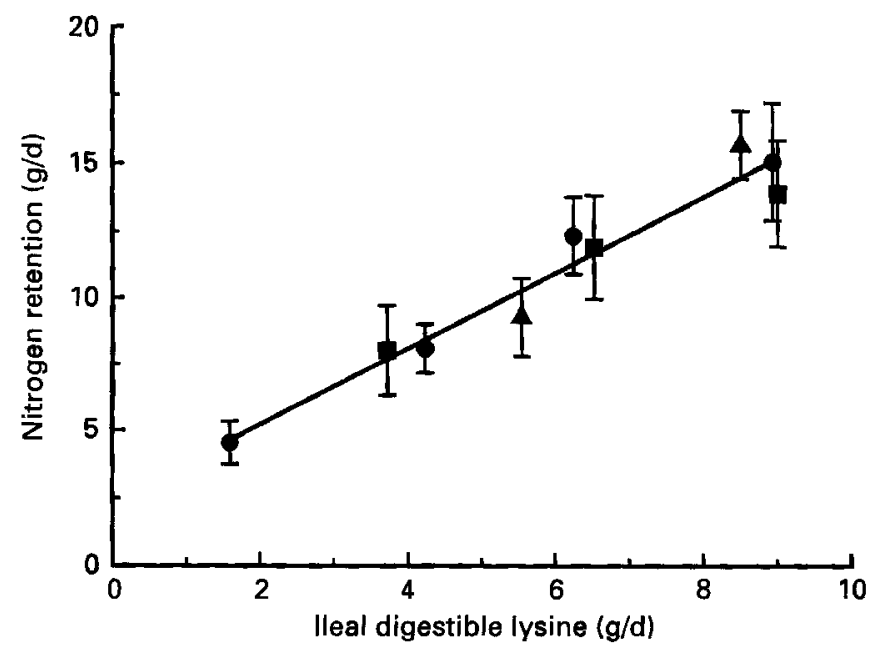

Fig. 1. Nitrogen retention in relation to ileal digestible lysine at three levels of protein: $100 \mathrm{~g}$ crude protein $/ \mathrm{kg}$ (O); $200 \mathrm{~g}$ crude protein $/ \mathrm{kg}(\mathbf{Q}) ; 300 \mathrm{~g}$ crude protein $/ \mathrm{kg}$ (A). Values are means for six pigs, with standard deviations indicated by vertical bars.

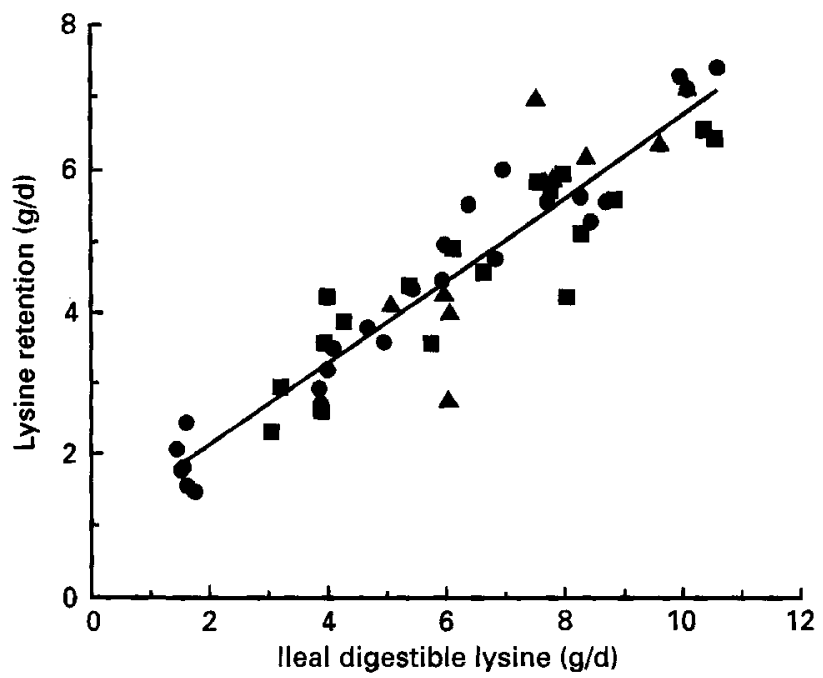

Fig. 2. Lysine retention as a function of ileal digestible lysine intake at different levels of protein intake, calculated from nitrogen retention assuming $65 \mathrm{mg}$ lysine $/ \mathrm{g}$ body protein $(\mathrm{N} \times 6.25)$ gained. Diets contained $100 \mathrm{~g}$ crude protein $/ \mathrm{kg}(\mathbf{O}) ; 200 \mathrm{~g}$ crude protein $/ \mathrm{kg}(\mathbf{G}) ; 300 \mathrm{~g}$ crude protein $/ \mathrm{kg}(\boldsymbol{\Delta})$. Individual values for each animal.

This regression, shown in Fig. 2, implies a marginal efficiency of utilization of absorbed lysine of 0.58 . However, the value of $65 \mathrm{mg}$ lysine/g body protein may be too low. Reviewing a number of publications, Susenbeth (1995) calculated a mean lysine concentration per $\mathrm{g}$ body protein of $68 \mathrm{mg}$ for pigs of $20-25 \mathrm{~kg}$ body weight and $71 \mathrm{mg}$ for pigs of $40-60 \mathrm{~kg}$ body weight. Interpolating these values gives a mean of $70 \mathrm{mg}$ lysine $/ \mathrm{g}$ body protein for the pigs $(30-50 \mathrm{~kg})$ in the present experiment. Accordingly, the relationship between lysine retained $(y, \mathrm{~g} / \mathrm{d})$ and the ileal digestible lysine intake $(x, \mathrm{~g} / \mathrm{d})$ was recalculated using this value, which gave the following equation:

$$
y=0.63 x+1.04 \quad\left(r^{2} 0.87\right) \text {. }
$$


The use of this slightly higher body lysine concentration in the calculation resulted in a higher efficiency of 0.63 .

\author{
DISCUSSION
}

\title{
Expt 1
}

It is generally accepted that, because the amino acid pattern of digesta is modified by the microflora during passage through the large intestine (Tanskley \& Knabe, 1984; Sauer \& Ozimek, 1986), amino acid digestibility determined at the terminal ileum gives a more accurate indication than faecal digestibility of the amount of amino acids absorbed by the animal. Various authors have shown that pigs cannot utilize amino acids 'disappearing' from the large intestine for $\mathrm{N}$ retention (Zebrowska, 1973; Just et al. 1981; Wünsche et al. 1982). Consequently, in the present experiment, ileal digestible lysine rather than total lysine concentration or faecal digestible lysine was used as a measure of lysine absorption. However, $\mathrm{N}$ is absorbed in the large intestine (Just et al. 1980; Deguchi \& Namioka, 1989) so faecal $\mathrm{N}$ digestibility was also determined and used in the calculation of $\mathrm{N}$ retention.

Apparent nitrogen (protein) digestibility. Digestibility of $\mathrm{N}$ at the end of the ileum was lower than the digestibility at the end of the gastrointestinal tract in all treatments, probably because of digestion and absorption of $\mathrm{N}$ in the large intestine (Sauer \& Ozimek, 1986; Deguchi \& Namioka, 1989). The difference between apparent ileal and faecal $N$ digestibility was about 10 percentage units. Increasing dietary crude protein from $100 \mathrm{~g} / \mathrm{kg}$ (diet 1) to $300 \mathrm{~g} / \mathrm{kg}$ (diet 8) increased both apparent ileal and apparent faecal digestibility of $N$ by about 4 and 6 percentage units respectively. This was presumably caused by a higher proportion of endogenous $\mathrm{N}$ in the digesta with the lower protein diets as shown by Fan et al. (1994).

Apparent lysine digestibility. It can be concluded that the aim of obtaining diets with similar amounts of ileal digestible lysine at different protein concentrations was achieved. However, diet 8 had approximately 11 percentage units higher ileal lysine digestibility than diet 1 . The large difference between diet 1 and diet 8 , using the same source of protein (diet 1 contained $333 \mathrm{~g}$ diet $8 / \mathrm{kg}$ and $667 \mathrm{~g}$ of a protein-free dilution mixture $/ \mathrm{kg}$ ), could be caused by a relatively high proportion of endogenous lysine in the digesta of pigs fed on a low-protein diet compared with pigs fed on diets containing larger amounts of protein (Furuya \& Kaji, 1989). Nevertheless, the change in lysine digestibility was much more pronounced than the change in $\mathbf{N}$ digestibility.

Fan et al. (1994) showed how apparent ileal lysine digestibility increased with dietary lysine to reach a plateau value of 0.86 with $8.5 \mathrm{~g}$ lysine $/ \mathrm{kg}$ diet. This is above the higher level used in the current experiment and that could explain the difference between diet 1 and diet 8.

At higher dietary protein (lysine) concentrations the influence of endogenous lysine appears to be negligible. Li et al. (1993) did not find any effect of protein concentration on lysine digestibility, using diets ranging from 165 to $255 \mathrm{~g}$ crude protein $/ \mathrm{kg}$ diet (i.e. 14.8 to $20.5 \mathrm{~g}$ lysine $/ \mathrm{kg}$ diet), produced by different ratios of soyabean meal and maize starch. A similar observation was made by Just et al. (1980). Nevertheless, at lower dietary protein (lysine) concentrations the higher proportion of endogenous lysine should be considered when comparing the results on an apparently-digestible-lysine basis.

The difference in lysine digestibility between diet 1 and diet 3 can be completely explained by the addition of lysine in free form, taken to be $100 \%$ digestible (Baker, 1994).

Expt 2

Some animals on the HP diet with the highest lysine deficiency (diet 8 ) refused some of their feed. A reduction of feed intake appears to be a protective mechanism against severe effects 
of amino acid imbalance (Leung \& Rogers, 1969; Tews et al. 1979). However, on all other diets the pigs ate all their feed so the aim of equalizing feed intake was largely achieved.

Effects of lysine intake on protein retention. From his review of a large number of experiments, Susenbeth (1995) calculated that, with diets first limiting in lysine, an increase of $1 \mathrm{~g}$ in lysine intake led to an increase of about $7.5 \mathrm{~g}$ in protein retention (based on slaughter experiments) in growing pigs weighing between 20 and $90 \mathrm{~kg}$. A similar result for pigs between 25 and $55 \mathrm{~kg}$ live weight can be derived from Yen et al. (1986) using diets based on cereals and soyabean meal. Assuming approximately $0.75-0.80$ (Tanksley \& Knabe, 1984) ileal digestibility of lysine in these diets, between 9.38 and $10.00 \mathrm{~g}$ protein would be retained per $\mathrm{g}$ ileal digestible lysine. These values agree with the estimate of $8.96 \mathrm{~g}$ protein retained per $g$ ileal digestible lysine intake determined in the present experiment.

The animals in the present experiment responded to an increase in lysine intake with a similar linear increase in protein retention, up to the maximum of about $11 \mathrm{~g}$ ileal digestible lysine, equivalent to about $13 \mathrm{~g}$ total lysine/d, at all three protein levels. It can be concluded that the daily lysine requirement was above these values.

From the present results it seems unnecessary, at least within the range of $100-300 \mathrm{~g}$ crude protein $/ \mathrm{kg}$, to consider the effects of protein excess in lysine-deficient diets. For such diets chemical score appears to give a satisfactory estimate of protein quality.

Efficiency of lysine utilization. Taking a constant value of $65 \mathrm{mg}$ or $70 \mathrm{mg}$ lysine/g protein gave efficiency values of 0.58 or 0.63 respectively. However, results from Batterham et al. $(1990 \mathrm{~b})$ indicate that body lysine concentration may depend on the deficiency of lysine in the diet and that the lysine concentration in the body protein gained, rather than in the final body protein, should be used for the calculation of efficiency of lysine utilization. From the data of Batterham et al. (1990b) the regression of lysine concentration in the retained body protein $(y, \mathrm{~g} / 16 \mathrm{~g} \mathrm{~N}) v$. ileal digestible lysine intake $(x, \mathrm{~g} / \mathrm{d})$ for the linear part of the response (3.49-10.84 g ileal digestible lysine intake; see Batterham et al. $(1990 \mathrm{~b})$ ) gave the following equation:

$$
y=0 \cdot 15 x+5 \cdot 27 \quad\left(r^{2} 0.99\right)
$$

Recalculating the present data values derived from this equation, the relationship between lysine retention $(y, \mathrm{~g} / \mathrm{d})$ and ileal digestible lysine intake $(x, \mathrm{~g} / \mathrm{d})$ was given by the equation:

$$
y=0.65 x+0.41 \quad\left(r^{2} 0.90\right) \text {. }
$$

Batterham et al. $(1990 \mathrm{a})$ determined the efficiency of lysine retention in pigs from $20 \mathrm{~kg}$ to $45 \mathrm{~kg}$ live weight using wheat-soyabean-meal diets. The lysine retained:ileal digestible lysine intake value was 0.63 . Based on available lysine intake rather than ileal digestible lysine intake the result was 0.64 . These values are in good agreement with the efficiency of $0.58-0.65$ estimated in the current experiment. However, in another study from the same group (Batterham et al. 1990 b) an efficiency of lysine retention per $\mathrm{g}$ ileal digestible lysine intake in soyabean meal of 0.86 was estimated using regression analysis. Excluding the treatment with the lowest lysine intake, which caused problems with the growth of the animals (E.S. Batterham, 1993; personal communication), results in a much lower efficiency of 0.77 . Bikker (1994) calculated a similar value of 0.74 for lysine utilization.

There could be several reasons for these differences in the estimates of the marginal efficiency of lysine utilization. First, the estimates depend critically on the correct estimation of digested lysine. The use of different methodologies for both amino acid analysis and digestibility measurements could give rise to discrepancies in the values deduced. Second, experiments using $\mathrm{N}$ balance might be expected to give different results from those based on comparative slaughter. On one hand, it is well established that balance methods tend to overestimate true rates of $\mathrm{N}$ retention; on the other hand, $\mathrm{N}$ balance is 
usually, as here, a short-term measurement in contrast with comparative slaughter experiments which last weeks or months and which consequently allow time for metabolic adaptations which may not be apparent in the shorter term. Third, the estimate is likely to be affected by the range of intakes over which it is made. At very low intakes greater conservation of the limiting amino acid, through more complete suppression of its oxidation, may lead to higher estimates of efficiency than are measured at intakes closer to the animal's requirement. Finally, variation in the efficiency of utilization of limiting amino acids may be an important component of genetic differences in performance. It is noteworthy that in the experiment of Batterham et al. $(1990 \mathrm{~b})$ intact male pigs had a considerably higher efficiency than females. It may, therefore, be inappropriate to expect a constant value for all animals.

We are grateful to Dr M. Franklin and Mr D. Hirst for statistical advice. This work was supported by the Scottish Office Agriculture and Fisheries Department and the financial support (SL) of Eurolysine SA and Degussa AG is gratefully acknowledged.

\section{REFERENCES}

Abebe, S. \& Morris, T. R. (1990). Note on the effects of protein concentration on responses to dietary lysine in chicks. British Poultry Science 31, 255-260.

Baker, D. H. (1994). Utilization of precursors for L-amino acids. In Amino Acids in Farm Animal Nutrition, pp. 37-61 [J. P. F. D'Mello, editor]. Wallingford: CAB International.

Batterham, E. S., Andersen, L. M., Baigent, D. R., Darnell, R. E. \& Taverner, M. R. (1990a). A comparison of the availability and ileal digestibility of lysine in cottonseed and soyabean meals for grower/finisher pigs. British Journal of Nutrition 64, 663-677.

Batterham, E. S., Andersen, L. M., Baigent, D. R. \& White, E. (1990b). Utilization of ileal digestible amino acids by growing pigs: effect of dietary lysine concentration on efficiency of lysine retention. British Journal of Nutrition 64, 81-94.

Benevenga, N. J. \& Steele, R. D. (1984). Adverse effects of excessive consumption of amino acids. Annual Review of Nutrition 4, 157-181.

Berschauer, F., Gaus, G., Cornelius, H., Kühl, J. \& Menke, K. H. (1980). Prediction of protein retention in rats

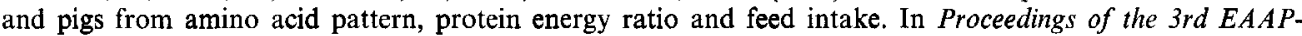
Symposium on Protein Metabolism and Nutrition, vol. 2. EAAP Publication no. 27, pp. $672-677$ pH. J. Oslage and K. Rohr, editors]. Braunschweig: European Association for Animal Production.

Bikker, P. (1994). Protein and lipid accretion in body components of growing pigs: effects of body weight and nutrient intake. PhD Thesis, University of Wageningen, The Netherlands.

Chamberlain, A. G. (1971). Protein requirements of the growing pig. In Pig Production, pp. $203-223$ [D. J. A Cole, editor]. London: Butterworths.

Cieslak, D. G. \& Benevenga, N. J. (1984a). The effect of amino acid excess on utilization by the rat of the limiting amino acid - lysine. Journal of Nutrition 114, 1863-1870.

Cieslak, D. G. \& Benevenga, N. J. (1984b). The effect of amino acid excess on utilization by the rat of the limiting amino acid - lysine and threonine at equalized food intakes. Journal of Nutrition 114, 1878-1883.

Cieslak, D. G. \& Benevenga, N. J. (1986). Response of rats to diets of equal chemical score: effect of lysine or threonine as the limiting amino acid and of an amino acid excess. Journal of Nutrition 116, 969-977.

Davidson, J., Matheson, J. \& Boyne, A. W. (1970). The use of automation in determining nitrogen by the Kjeldahl method, with final calculation by computer. Analyst 95, 181-193.

Deguchi, E. \& Namioka, S. (1989). Synthesis ability of amino acids and protein from non-protein nitrogen and role of intestinal flora on this utilization in pigs. Bifidobacteria and Microflora 8, 1-12.

D'Mello, J. P. F. (1988). Dietary interactions influencing amino acid utilisation by poultry. Worlds Poultry Science Journal 44, 92-102.

D'Mello, J. P. F. (1994). Amino acids imbalances, antagonisms and toxicities. In Amino Acids in Farm Animal Nutrition, pp. 63-97 [J. P. F. D'Mello, editor]. Wallingford: CAB International.

D'Mello, J. P. F. \& Lewis, D. (1970a). Amino acid interactions in chick nutrition. 1. The interrelationship between lysine and arginine. British Poultry Science 11, 299 311.

D'Mello, J. P. F. \& Lewis, D. $(1970 \mathrm{~b})$. Amino acid interactions in chick nutrition. 2. Interrelationships between leucine, isoleucine and valine. British Poultry Science 11, 313-323.

D'Mello, J. P. F. \& Lewis, D. (1970c). Amino acid interactions in chick nutrition. 3. Interdependence in amino acid requirements. British Poultry Science 11, 367-385.

Fan, M. Z., Sauer, W. C. \& Lien, K. A. (1994). Effect of dietary amino acid level on the determination of apparent 
ileal amino acid digestibility in pigs. In Proceedings of the VIth International Symposium on Digestive Physiology in Pigs, vol. 1. EAAP Publication no. 80, pp. 25-27 [W. B. Souffrant and H. Hagemeister, editors]. Dummerstorf: Forschungsinstitut für die Biologie landwirtschaftlicher Nutztiere.

Fisher, H., Griminger, P., Leveille, G. A. \& Shapiro, R. (1960). Quantitative aspects of lysine deficiency and amino acid imbalance. Journal of Nutrition 71, 213-220.

Fuller, M. F., Cadenhead, A., Mollison, G. \& Sève, B. (1987a). Effects of the amount and quality of dietary protein on nitrogen metabolism and heat production in growing pigs. British Journal of Nutrition 58, 277-285.

Fuller, M. F., Livingstone, R. M., Baird, B. A. \& Atkinson, T. (1979). The optimal amino acid supplementation of barley for the growing pig. 1. Response of nitrogen metabolism to progressive supplementation. British Journal of Nutrition 41, 321-331.

Fuller, M. F., Reeds, P. J., Cadenhead, A., Sève, B. \& Preston, T. (1987 b). Effects of the amount and quality of dietary protein on nitrogen metabolism and protein turnover of pigs. British Journal of Nutrition 58, 287-300.

Furuya, S. \& Kaji, Y. (1989). Estimation of the true ileal digestibility of amino acids and nitrogen from their apparent values for growing pigs. Animal Feed Science and Technology 26, 271-285.

Genstat 5 Committee (1993). Genstat 5.2. Oxford: Clarendon Press.

Harper, A. E., Benevenga, N. J. \& Wohlhueter, R. M. (1970). Effects of ingestion of disproportionate amounts of amino acids. Physiological Reviews 50, 428-558.

Henry, Y., Colléaux, Y. \& Sève, B. (1992). Effects of dietary level of lysine and of level and source of protein on feed intake, growth performance, and plasma amino acid pattern in the finishing pig. Journal of Animal Science 70, 188-195.

Just, A., Jørgensen, H. \& Fernández, J. A. (1981). The digestive capacity of the caecum-colon and the value of the nitrogen absorbed from the hind gut for protein synthesis in pigs. British Journal of Nutrition 46, 209-219.

Just, A., Sauer, W. C. \& Jørgensen, H. (1980). The influence of diet on the apparent ileal and faecal digestibility of protein and amino acids in pigs. In Proceedings of the 3rd EAAP-Symposium on Protein Metabolism and Nutrition, vol. I. EAAP Publication no. 27, pp. 215-219 [H. J. Oslage and K. Rohr, editors]. Braunschweig: European Association for Animal Production.

Klay, R. F. (1964a). The lysine requirement for growth of pigs at four protein levels. Journal of Animal Science 23, 881 (Abstr).

Klay, R. F. (1964b). Lysine and nitrogen utilization by pigs at four protein levels. Journal of Animal Science 23, 881 (Abstr).

Langer, S. \& Fuller, M. F. (1995)., Lysine utilization in growing pigs at three different levels of protein. Proceedings of the Nutrition Society 54, 64A.

Leung, P. M.-B. \& Rogers, Q. R. (1969). Food intake: regulation by plasma amino acid pattern. Life Sciences 8 (2), 1-9.

Li, S., Sauer, W. C. \& Fan, M. Z. (1993). The effect of dietary crude protein levels on ileal and fecal amino acid digestibility in early-weaned pigs. Journal of Animal Physiology and Animal Nutrition 70, 117-128.

Menke, K. H., Gruber, F. \& Gaus, G. (1983). The product of amino acids functions as a measure of protein quality for pigs. In IVth International Symposium on Protein Metabolism and Nutrition, pp. $431-434$ [R. Pion, M. Arnal and D. Bonin, editors]. Paris: INRA.

Mitchell, H. H. \& Block, R. J. (1946). Some relationships between the amino acid contents of proteins and their nutritive values for the rat. Journal of Biological Chemistry 163, 599-620.

Morris, T. R., Al-Azzawi, K., Gous, R. M. \& Simpson, G. L. (1987). Effects of protein concentration on responses to dietary lysine by chicks. British Poultry Science 28, 185-195.

Morup, I. L. K. \& Olesen, E. S. (1976). New method for prediction of protein value from essential amino acid pattern. Nutrition Reports International 13, 355-365.

Sauer, W. C. \& Ozimek, L. (1986). Digestibility of amino acids in swine: results and their practical applications. A review. Livestock Production Science 15, 367-388.

Stevenson, A. E. \& Clare, N. T. (1963). Measurement of feed intake by grazing cattle and sheep. IX. Determination of chromic oxide in faeces using an auto analyzer. New Zealand Journal of Agricultural Research 6, 121-126.

Susenbeth, A. (1995). Factors affecting lysine utilization in growing pigs. An analysis of literature data. Livestock Production Science 43, 193-204.

Tanksley, T. D. \& Knabe, D. A. (1984). Ileal digestibilities of amino acids in pig feeds and their use in formulating diets. In Recent Advances in Animal Nutrition, pp. 75-95 [W. Haresign and D. J. A. Cole, editors]. London: Butterworths.

Tews, J. K., Lee Kim, Y.-W. \& Harper, A. E. (1979). Induction of threonine imbalance by dispensable amino acids: relation to competition for amino acid transport into the brain. Journal of Nutrition 109, 304-315.

Udén, P., Colucci, P. E. \& Van Soest, P. J. (1980). Investigation of chromium, cerium and cobalt as markers in digesta. Rate of passage studies. Journal of the Science of Food and Agriculture 31, 625-632.

Wang, T.C. \& Fuller, M. F. (1989). The optimum dietary amino acid pattern for growing pigs. 1. Experiments by amino acid deletion. British Journal of Nutrition 62, 77-89.

Wünsche, J., Hennig, U., Meinl, M., Kreienbring, F. \& Bock, H. D. (1982). Investigations of the absorption and utilization of amino acids infused into the caccum of growing pigs. 1 . N-balance measuring with regard to the 
utilization of lysine and isoleucine and the isoleucine requirement of growing pigs. Archiv für Tierernährung 32, 337-348.

Yen, H. T., Cole, D. J. A. \& Lewis, D. (1986). Amino acid requirements of growing pigs. 7. The response of pigs from 25-55 kg live weight to dietary ideal protein. Animal Production 43, 141-154.

Zebrowska, T. (1973). Digestion and absorption of nitrogenous compounds in the large intestine of pigs. Roczniki Nauk Rolniczych 95B, 85-90. 